\title{
Antibacterial, Molecular Docking, DNA Binding and Photocleavage Studies on Novel Heterocyclic Pyrazoles
}

\author{
N. Sharath ${ }^{1}$, Halehatty S. Bhojya Naik ${ }^{1^{*}}$, B. Vinay Kumar ${ }^{1}$ \\ and Joy Hoskeri ${ }^{2}$ \\ ${ }^{1}$ Department of Studies and Research in Industrial Chemistry, School of \\ Chemical Sciences, Kuvempu University, Shankaraghatta-577451, India. \\ ${ }^{2}$ Department of Studies and Research in Bio-informatics, School of \\ Biological Sciences, Kuvempu University, Shankaraghatta-577451, India.
}

Research Article

Received $12^{\text {th }}$ March 2011

Accepted 27 $7^{\text {th }}$ April 2011

Online Ready $2^{\text {nd }}$ May 2011

\section{ABSTRACT}

The antibacterial activity, in-silico DNA molecular docking, DNA binding and photo cleavage studies of newly synthesized pyrazole is described. Antibacterial potential of these compounds screened against a wide range of Gram-positive and Gram-negative bacteria showed significant zone of inhibition and MIC with standard drug ciproflaxin is investigated. Among all the orientation of binding, fourth orientation showed significant binding and revealed that the binding and docking energy of $4 a$ was -8.62 and -8.66 and inhibition constant $7.46 \times \mathrm{e}^{-6}$. The absorption spectra showed the dynamic interaction with CT DNA and as proficient DNA intercalator $\left(K_{b}=4.5 \times 10^{4} \mathrm{M}^{-1}\right)$. The viscosity measurements and thermal denaturation affords the positive results towards DNA intercalation in both the studies. The light induced DNA damage was pragmatic in the absence of various "inhibitors" shows in photo cleavage activities at $360 \mathrm{~nm}$.

Keywords: CT-DNA; intercalator; in-silico; molecular docking; photocleavage; pyrazole;

\section{INTRODUCTION}

The heterocyclic compounds results in enormous significance in the field of drug discovery process. Substituted oxazole, pyrazole and their analogues have been used as precursors 
for synthesis of various biologically dynamic molecules, pyrazole derivatives as brain-derived neurotrophic factor inducers (Maekawa et al., 2003), analgesic, (Lunzer et al., 2007), trypanocidal activity (Sao Paulo et al., 2001), anti-mitotic agents with pro-apoptotic activity (Uckun et al., 2001), antifungal activity (Laure et al., 1988), anti-inflammatory (Gill et al., 2008), anti-depressant (Loaiza-Rodriguez et al., 2004), anti-cancer (Benedetti et al.,1994), anti-diabetic and anti- obesity (Viti et.al.,1994). Pyrazolidinones had attracted attention as a new class of active synthetic antibiotics with a unique mechanism of bacterial protein synthesis inhibition (Cohen 2000; Brickner 1996; Barbachyn et al., 1997; Shinabarger 1999). The pyrazole with ether linkage at fifth position had good anti-bacterial, anti-inflammatory and CNS activity (Desai et al., 2000; Aglawe et al., 2003) and play an imperative role in the catalytic antioxidant activity.

Since, Selenium resembles sulfur, topical studies revealed that the intramolecularly stabilized organoselenium, sulfur and oxygen containing compounds in many of its properties have isosteric nature (Bhojya Naik et al., 2009).

The biological and pharmaceutical activities of different selenium compounds are of special interest since they are active sites of a large number of selenium dependent enzymes (Klayman et al., 1973) and help in prevention of cancer (Fisher et al., 1991). On the other hand, literature survey showed that the evidence of antitumor activity is due to the compound intercalation between the base pair of DNA and interference with normal functioning of the enzyme topoisomerase II, which is involved in the breaking and releasing of DNA strands (Gatto et al., 1999).

There are variety of studies concerning DNA cleavage by photo sensitizers which either initiate a single electron transfer from a base to the triplet state of chromophores, which often leads to a selective cleavage at the $5^{1}-\mathrm{G}$ of $\mathrm{GG}$ step in duplex DNA, or generate active oxygen species (Howell et al., 2001; Tornoe et al., 2002; Angell et al., 2005; Roma et.al., 2000; Chen et al., 2001).

Above literature manifest the biological properties of compounds with intermolecular atoms has made lashing force for increasing interest in the synthetic routes. With these facts and in continuation of research exploration of pyrazole with heteroatoms, we designed and studied the in-silico molecular docking of newly synthesized compounds. With this, antibacterial potential of our newly synthesized compounds against a wide range of Gram-positive and Gram-negative bacteria was studied with four bacterial strains. To validate the ethnotherapeutic claims of these S/Se compounds the antibacterial activity are studied. By considering the docking hypothesis, the DNA binding, viscometric measurements, thermal denaturation methods and photo nuclease activities were presented. With these results the present study reports a newly synthesized heterocyclic fused pyrazoles with biological parameters.

\section{MATERIALS AND METHODS}

\subsection{CHEMICALS AND INSTRUMENTS}

The melting points are determined by capillary methods and are uncorrected. The IR spectra were recorded on a Shimadzu model impact $8400 \mathrm{~S}$ FT-IR spectrometer $\left(\mathrm{KBr}\right.$ pellets, $3 \mathrm{~cm}^{-1}$ resolution). ${ }^{1} \mathrm{H}$ NMR spectra on a Bruker $400 \mathrm{MHz}$ and mass spectra were recorded on ESMS Kratos pekompact SEQ V1.2.2 spectrometer and UV-visible absorption spectra are recorded using Shimadzu 1650 model. Micro-wave oven from kenstar-2450Hz. Viscosity 
measurements are studied by semi micro dilution capillary viscometer (Viscomatic Fica $\mathrm{MgW}$ ) with a thermostated bath D40S. Unless or otherwise mentioned, all chemicals are purchased from himedia. All solvents are freshly distilled. CTDNA is purchased from Bangalore Gene, Bangalore, India. Tris $-\mathrm{HCl}$ buffer $(5 \mathrm{mMT}$ ris $-\mathrm{HCl}, 50 \mathrm{MNaCl}, \mathrm{pH}=7.2$, Tris=Tris (hydroxymethyl) aminomethane) solution is prepared using deionized doubledistilled water. TLC analysis was carried out using the precoated silica gel $\mathrm{GF}_{454}$ plates.

\subsection{GENERAL EXPERIMENTAL PROCEDURE FOR THE PREPARATION OF CHALCONES 3(a-e).}

$10 \mathrm{mmol}$ of Acetyl derived compound is dissolved in the alcohol with $10 \mathrm{mmol} 2$-chloroquinoline carbaldehyde in presence of 2.5 equivalence of $\mathrm{K}_{2} \mathrm{CO}_{3}$ with stirring for 30 minutes in ice cold condition (Mokle et al., 2010). Then reaction is stirred in room temperature for 5- 6 hrs and checked for TLC for the completion of the reaction. The compound was quenched on ice then acidified with dilute $\mathrm{HCl}$ and then filtered, dried and recrystallized in the ethanol.

\subsection{1 [3-[3-(2-chloro-quinolin-3-yl)-acryloyl]-1-selena-9-aza-anthracen-2-one] (3a)}

Creamish white in colour, solid, yield-84\%, melting point $\left(180-182^{\circ} \mathrm{C}\right)$. FT-IR $(\mathbf{K B r})(\mathbf{v})$ 2854(C-H str), 1640(C= O), 1612 ( $\mathrm{C}=\mathrm{N}), 1180$ (C-Se-C), 1578, 1542, 1474 (Ar-C=Cstr), 1036.8(C-N), 642.5(C-Cl) cm ${ }^{-1} .{ }^{1} \mathrm{H}-\mathrm{NMR}$ (DMSO-d $\left.\mathrm{d}_{6}\right) \delta 6.2(\mathrm{~d}, 1 \mathrm{H},-\mathrm{CO}-\mathrm{CH}=), 7.2(\mathrm{~d}, 1 \mathrm{H},=\mathrm{CH}-$ Ar), $7.6-8.1(\mathrm{~m}, 9 \mathrm{H}, \mathrm{Ar}-\mathrm{H}), 8.5(\mathrm{~s}, 1 \mathrm{H}, \mathrm{Ar}-\mathrm{H}), 8.7(\mathrm{~s}, 1 \mathrm{H}, \mathrm{Ar}-\mathrm{H})$. Elemental analysis Calculated(Found): $\mathrm{C}_{24} \mathrm{H}_{13} \mathrm{Cl} \mathrm{N}_{2} \mathrm{O}_{2} \mathrm{Se}: \mathrm{C}, 60.59$ (60.56); H, 2.75 (2.78) ; N, 5.89 (5.91). Mass ES-MS m/z (\%) [M] $]^{+}[476.78]^{+}$.

\subsection{2 [3-[3-(2-chloro-quinolin-3-yl)-acryloyl]-1-thia-9-aza-anthracen-2-one](3b)}

Light brown in colour, solid, yield-76\%, melting point $\left(146-148^{\circ} \mathrm{C}\right)$. FT-IR $(\mathrm{KBr})(\mathbf{v})$ 2850(CHstr), 1637(C=O) $1610(\mathrm{C}=\mathrm{N}), 1575,1544,1468\left(\mathrm{Ar}-\mathrm{C}=\mathrm{C}\right.$ str), 1038.8(C-N), 642.5(C-Cl) cm $\mathrm{cm}^{-1}$. ${ }^{1} \mathrm{H}-N M R\left(\mathrm{DMSO}-\mathrm{d}_{6}\right) \delta 6.4(\mathrm{~d}, 1 \mathrm{H},-\mathrm{CO}-\mathrm{CH}=$ ), $7.4(\mathrm{~d}, 1 \mathrm{H},=\mathrm{CH}-\mathrm{Ar}), 7.5-8.05(\mathrm{~m}, 9 \mathrm{H}, \mathrm{Ar}-\mathrm{H}), 8.4$ $(\mathrm{s}, 1 \mathrm{H}, \mathrm{Ar}-\mathrm{H}), 8.6(\mathrm{~s}, 1 \mathrm{H}, \mathrm{Ar}-\mathrm{H})$,; Elemental analysis Calculated (found) $\mathrm{C}_{24} \mathrm{H}_{13} \mathrm{ClN}_{2} \mathrm{O}_{2} \mathrm{~S}$ : $\mathrm{C}$, 67.21(67.24); H, 3.06 (3.04); N, 6.53 (6.55). Mass ES-MS m/z (\%) [M] $]^{+}\left[[427.8]^{+}\right.$.

\subsection{3. [3-[3-(2-hydroxy-quinolin-3-yl)-acryloyl]-1-thia-9-aza-anthracen-2-one](3c)}

Yellowish brown in colour, solid, yield-79\%, melting point $\left(132-134^{\circ} \mathrm{C}\right)$. FT-IR $(\mathbf{K B r})(\mathbf{v})$ 2852(C-H str), $1640(\mathrm{C}=\mathrm{O}), 1616(\mathrm{C}=\mathrm{N}), 1224(\mathrm{C}-\mathrm{S}-\mathrm{C}), 1572,1542,1472$ (Ar-C=C str), 3616(Ar-OH) $\quad \mathrm{cm}^{-1} .{ }^{1} \mathrm{H}-\mathrm{NMR} \quad\left(\mathrm{DMSO}-\mathrm{d}_{6}\right) \quad \delta \quad 6.6(\mathrm{~d}, 1 \mathrm{H},-\mathrm{CO}-\mathrm{CH}=), \quad 7.3(\mathrm{~d}, 1 \mathrm{H},=\mathrm{CH}-\mathrm{Ar}), \quad 7.4-$ 8.1 (m,9H,Ar-H), $8.5(\mathrm{~s}, 1 \mathrm{H}, \mathrm{Ar}-\mathrm{H}) \quad, \quad 8.6(\mathrm{~s}, 1 \mathrm{H}, \mathrm{Ar}-\mathrm{H}), \quad 8.8(\mathrm{~s}, 1 \mathrm{H}, \mathrm{Ar}-\mathrm{OH})$;Elemental analysis Calculated (found) $\mathrm{C}_{24} \mathrm{H}_{14} \mathrm{~N}_{2} \mathrm{O}_{3} \mathrm{~S}$ : C, 70.23 (70.25); $\mathrm{H}, 3.44$ (3.42); $\mathrm{N}, 6.83$ (6.81). Mass ESMS m/z (\%) [M] : [411.40] $]^{+}$.

\subsection{4 [2-[3-(2-chloro-quinolin-3-yl)-acryloyl]-4-oxa-5-aza-phenanthren-3-one] (3d)}

Pale yellow in colour, solid, yield-74\%, melting point $\left(128-130^{\circ} \mathrm{C}\right)$. FT-IR $(\mathbf{K B r})(\mathbf{v}) 2850$ (CH str), 1640 (C=O), 1100(C-O-C), 1612(C=N), 1577, 1538, 1466(Ar-C=Cstr), 1040.2(C-N), 645.5(C-Cl) cm ${ }^{-1} .{ }^{1} \mathrm{H}-\mathrm{NMR}$ (DMSO- $\left.\mathrm{d}_{6}\right) \quad \delta \quad 7.0(\mathrm{~d}, 1 \mathrm{H},-\mathrm{CO}-\mathrm{CH}=), \quad 7.6(\mathrm{~d}, 1 \mathrm{H},=\mathrm{CH}-\mathrm{Ar}), \quad 7.2-$ $8.2(\mathrm{~m}, 8 \mathrm{H}, \mathrm{Ar}-\mathrm{H}), 8.3(\mathrm{~s}, 1 \mathrm{H}, \mathrm{Ar}-\mathrm{H}) 8.81(\mathrm{~d}, 1 \mathrm{H}, \mathrm{Ar}-\mathrm{H}), 8.83(\mathrm{~s}, 1 \mathrm{H}, \mathrm{Ar}-\mathrm{H})$ Elemental analysis Calculated (found) $\mathrm{C}_{24} \mathrm{H}_{13} \mathrm{ClN}_{2} \mathrm{O}_{3}$ : C, 69.83(69.79); H, 3.17(3.21); N, 6.79(6.75). Mass ESMS m/z (\%) [M] : [413.82] 


\subsection{5 [2-[3-(2-chloro-quinolin-3-yl)-acryloyl]-benzo[f]chromen-3-one] (3e)}

Light green in colour solid, yield-81\%, melting point $\left(118-120^{\circ} \mathrm{C}\right)$. FT-IR $(\mathbf{K B r})(\mathbf{v}) 2849(\mathrm{C}-$ Hstr), 1637(C=O), 1090(C-O-C), 1615 (C=N), 1578, 1538, 1472 (Ar-C=C str), 1035.8(C-N), 646.5(C-Cl) cm ${ }^{-1}$. ${ }^{1} \mathrm{H}-\mathrm{NMR} \quad$ (DMSO-d 6$) \quad \delta \quad 6.6(\mathrm{~d}, 1 \mathrm{H},-\mathrm{CO}-\mathrm{CH}=), 6.9(\mathrm{~d}, 1 \mathrm{H},=\mathrm{CH}-\mathrm{Ar}), 7.2-$ $8.3(\mathrm{~m}, 10 \mathrm{H}, \mathrm{Ar}-\mathrm{H}), 8.35(\mathrm{~s}, 1 \mathrm{H}, \mathrm{Ar}-\mathrm{H}), 8.8(\mathrm{~s}, 1 \mathrm{H}, \mathrm{Ar}-\mathrm{H})$. Elemental analysis Calculated (found) $\mathrm{C}_{25} \mathrm{H}_{14} \mathrm{CINO}_{3}$ : C, 72.91(72.88); $\mathrm{H}, 3.43(3.38) ; \mathrm{N}, 3.40$ (3.36). Mass ES-MS m/z (\%) [M]": [412.82] $]^{+}$.

\subsection{GENERAL EXPERIMENTAL PROCEDURE FOR THE PREPARATION OF PYRAZOLE}

The compounds 3(a-e) of chalcone 1 equivalent and 1.25 equivalent hydrazine hydrate is added in dried ethanol $(10 \mathrm{ml})$ containing catalytic amount of glacial acetic acid was refluxed for 3-4 hrs with stirring(Adnan 2004). The reaction mixture was checked for TLC for the completion of reaction, and then it was concentrated, filtered, dried and recrystallized from ethyl acetate 4(a-e).

\subsection{1[3-[5-(2-chloro-quinolin-3-yl)-2H-pyrazol-3-yl]-1-seleno-9-aza-anthracen-2-one](4a)}

White in colour, solid, yield-78\%, melting point $\left(166-168^{\circ} \mathrm{C}\right)$. FT-IR $(\mathbf{K B r})$ (v) 3336.9(C$\mathrm{NH}), 2854(\mathrm{C}-\mathrm{H}$ str), $1634(\mathrm{C}=\mathrm{O}), 1614(\mathrm{C}=\mathrm{N}), 1584,1542,1474$ (Ar-C=C str), 1032.8(C-N), 639.5(C-Cl) cm ${ }^{-1}$. ${ }^{1} \mathrm{H}-\mathrm{NMR}$ (DMSO-d $\left.\mathrm{d}_{6}\right) \delta 6.4(\mathrm{~d}, 1 \mathrm{H},-\mathrm{CH}=), 7.3-8.2(\mathrm{~m}, 10 \mathrm{H}, \mathrm{Ar}-\mathrm{H}), 8.7(\mathrm{~s}, 1 \mathrm{H}, \mathrm{Ar}-$ $\mathrm{H}), 13.2(\mathrm{~s}, 1 \mathrm{H},-\mathrm{NH})$ Elemental analysis Calculated (found) $\mathrm{C}_{24} \mathrm{H}_{13} \mathrm{ClN}_{4} \mathrm{OSe}$ : C, 59.09(59.20); $\mathrm{H}, 2.69$ (2.64); N, 11.49 (11.57). Mass ES-MS m/z (\%) [M] : [488.79] ${ }^{+}$.

\subsection{2 [3-[5-(2-chloro-quinolin-3-yl)-2H-pyrazol-3-yl]-1-thia-9-aza-anthracen-2-one](4b)}

Yellowish brown in colour, solid, yield-68\%, melting point $\left(110-112^{\circ} \mathrm{C}\right)$. FT-IR $(\mathrm{KBr})(\mathbf{v})$ 3336.9(C-NH), 2850(C-H str), $1637(\mathrm{C}=\mathrm{O}), 1610(\mathrm{C}=\mathrm{N}), 1580,1540,1470(\mathrm{Ar}-\mathrm{C}=\mathrm{C}$ str), 1032.8(C-N), 640.5(C-Cl) cm ${ }^{-1}$. ${ }^{1} \mathrm{H}-\mathrm{NMR}$ (DMSO-d 6 ) $\delta 6.2(\mathrm{~d}, 1 \mathrm{H},-\mathrm{CH}=), 7.4-8.05(\mathrm{~m}, 10 \mathrm{H}, \mathrm{Ar}-$ $\mathrm{H}), 8.6(\mathrm{~s}, 1 \mathrm{H}, \mathrm{Ar}-\mathrm{H}), 13.5(\mathrm{~s}, 1 \mathrm{H},-\mathrm{NH})$, Elemental analysis Calculated (found) $\mathrm{C}_{24} \mathrm{H}_{13} \mathrm{ClN}_{4} \mathrm{OS}$ : $\mathrm{C}, 65.38(65.36) ; \mathrm{H}, 2.97(2.92) ; \mathrm{N}, 12.71$ (12.64). Mass ES-MS m/z (\%) [M] $]^{+}$[441.90] ${ }^{+}$.

\subsection{3 [3-[5-(2-hydroxy-quinolin-3-yl)-2H-pyrazol-3-yl]-1-thia-9-aza-anthracen-2-one](4c)}

Light green in colour, solid, yield-70\%, melting point $\left(120-122^{\circ} \mathrm{C}\right)$. FT-IR (KBr) (v) 3338.9(C-NH), 2855(C-H str), 1640(C=O), 1614(C=N), 1578, 1542, 1468(Ar-C=Cstr), 1034.8(C-N), 645.5(C-Cl), $3614.8(\mathrm{Ar}-\mathrm{OH}) \mathrm{cm}^{-1}{ }^{1}{ }^{1} \mathrm{H}-\mathrm{NMR}$ (DMSO-d 6 ) $\delta 6.3(\mathrm{~d}, 1 \mathrm{H},-\mathrm{CH}=), 7.4-$ $8.05(\mathrm{~m}, 10 \mathrm{H}, \mathrm{Ar}-\mathrm{H}), 8.2(\mathrm{~s}, 1 \mathrm{H}, \mathrm{Ar}-\mathrm{H}), 13.7(\mathrm{~s}, 1 \mathrm{H},-\mathrm{NH}), 8.9(\mathrm{~s}, 1 \mathrm{H},-\mathrm{OH})$. Elemental analysis Calculated (found) $\mathrm{C}_{24} \mathrm{H}_{14} \mathrm{~N}_{4} \mathrm{O}_{2} \mathrm{~S}$ : C, 68.23 (68.28); H, 3.34(3.39); N, 13.26(13.3). Mass ESMS m/z (\%) [M] $]^{+}[423.40]^{+}$.

\subsection{4 [2-[5-(2-chloro-quinolin-3-yl)-2H-pyrazol-3-yl]-4-oxa-5-aza-phenanthren-3-one](4d)}

Pale green in colour, solid, yield-74\%, melting point $\left(114-116^{\circ} \mathrm{C}\right)$. FT-IR $(\mathrm{KBr})(\mathbf{v})$ 2852(CH str), 1636(C=O), 1090(C-O-C), 1608(C=N), 1579, 1539, 1472(Ar-C=C str), 1034.8(C-N), 643.5(C-Cl), $\mathrm{cm}^{-1}{ }^{1}{ }^{1} \mathrm{H}-\mathrm{NMR}$ (DMSO-d $\left.\mathrm{d}_{6}\right) \delta 6.2(\mathrm{~d}, 1 \mathrm{H},-\mathrm{CH}=), 7.4-8.5(\mathrm{~m}, 10 \mathrm{H}, \mathrm{Ar}-\mathrm{H}), 8.7(\mathrm{~s}, 1 \mathrm{H}$, Ar-H), $13.5(\mathrm{~s}, \quad 1 \mathrm{H},-\mathrm{NH})$. Elemental analysis Calculated (found) $\mathrm{C}_{24} \mathrm{H}_{13} \mathrm{ClN}_{4} \mathrm{O}_{2}$ : C,67.85(67.80); H, 3.08(3.15); N, 13.19(13.14). Mass ES-MS m/z (\%) [M] : [425.82] $]^{+}$. 


\subsection{5 [2-[5-(2-chloro-quinolin-3-yl)-2H-pyrazol-3-yl]- benzo[f]chromen-3-one](4e)}

White in colour, solid, yield-72\%, melting point $\left(106-108^{\circ} \mathrm{C}\right) . \mathbf{F T}-\mathrm{IR}(\mathrm{KBr})(\mathbf{v}) 2847(\mathrm{C}-\mathrm{H}$ str), $1640(\mathrm{C}=\mathrm{O}), 1096(\mathrm{C}-\mathrm{O}-\mathrm{C}), 1610(\mathrm{C}=\mathrm{N}), 1580,1540,1470(\mathrm{Ar}-\mathrm{C}=\mathrm{C}$ str), 1032.8(C-N), 645.5(C-Cl) cm ${ }^{-1} .{ }^{1} \mathrm{H}-\mathrm{NMR}$ (DMSO-d $\left.\mathrm{d}_{6}\right) \delta 6.4(\mathrm{~d}, 1 \mathrm{H},-\mathrm{CH}=), 7.2-8.1(\mathrm{~m}, 11 \mathrm{H}, \mathrm{Ar}-\mathrm{H}), 8.5(\mathrm{~s}, 1 \mathrm{H}$, Ar-H), $13.7(\mathrm{~s}, \quad 1 \mathrm{H}, \quad-\mathrm{NH})$. Elemental analysis Calculated (found) $\mathrm{C}_{25} \mathrm{H}_{14} \mathrm{ClN}_{3} \mathrm{O}_{2}$ : C, 70.84(70.80); H, 3.33 (3.38); N, 9.91(9.87). Mass ES-MS m/z (\%) [M] $]^{+}:[424.82]^{+}$.

\subsection{ANTIBACTERIAL ASSAY}

The agar well diffusion method (Udupa et al., 1995) is used for the assessment of antibacterial activity of the test samples. Medium (peptone $10 \mathrm{~g} / \mathrm{l}$, yeast extract $5 \mathrm{~g} / \mathrm{l}$, sodium chloride $10 \mathrm{~g} / \mathrm{l}$, agar-agar $15 \mathrm{~g} / \mathrm{l}, \mathrm{pH} 7.2)$ was poured into sterilized Petri dishes $(90 \mathrm{~mm}$ diameter). LB broth containing $100 \mathrm{ml}$ of 24-h incubated cultures of the respective clinical isolates and the ATCC and MTCC strains was spread separately on the agar medium. Wells are created using a sterilized cork borer under aseptic conditions. Cell count was taken using haemo-cytometer after loading $10 \mathrm{ml}$ of the cell suspension in PBS and no. of cells $/ \mathrm{mL}$ is calculated. the final concentration of each strain was 106 cells $/ \mathrm{mL}$. Cultures are grown for 3 days at $37{ }^{\circ} \mathrm{C}$ and wells are made using cork borer and $100 \mathrm{ml}(10 \mathrm{mg} / \mathrm{mL})$ of test compounds is loaded to each wells. The reference antibacterial agent ciprofloxacin is (10 $\mathrm{mg} / \mathrm{mL}$ ) loaded in the corresponding wells. Plates were then incubated at $37{ }^{\circ} \mathrm{C}$ for $48 \mathrm{~h}$. At the end of the incubation period, inhibition zones formed on the medium are evaluated in millimeters.

\subsubsection{MINIMUM INHIBITORY CONCENTRATIONS (MICS)}

The minimum inhibitory concentrations (MICs) of the newly synthesized compounds $4 a$ and $4 \mathrm{~b}$ are determined by micro dilution techniques in LB broth, according to Clinical and Laboratory Standards Institute (CLSI), USA guidelines. The bacterial inoculates are prepared in the same medium with density adjusted to a 0.5 McFarland turbidity standard colony forming units and diluted 1:10 for the broth micro dilution procedure. The microtiter plates are incubated at $37{ }^{\circ} \mathrm{C}$ and MIC is determined after $24 \mathrm{~h}$ of incubation. The highest activity of the standard drug compared with those of our synthesized compounds $4 \mathrm{a}$ and $4 \mathrm{~b}$ indicated potent antibacterial activity (Table 4).

\subsubsection{BACTERIAL STRAINS}

Of the six clinical strains three of the bacterial pathogens belong to Gram-positive S. aureus - ATCC-29737, and S. pyogenes - NCIM-2608 and Gram-negative bacteria such as P. aeruginosa - ATCC-20852 and B. subtilis - NCIM-2010 are collected from National Chemical Laboratory (NCL), Pune, India. All the bacterial microorganisms are maintained at $30^{\circ} \mathrm{C}$ in Brain Heart Infusion (BHI) containing $17 \%(\mathrm{v} / \mathrm{v})$ glycerol. Before testing, the suspensions are transferred to LB broth and cultured overnight at $37{ }^{\circ} \mathrm{C}$. Inocula are prepared by adjusting the turbidity of the medium to match the $0.5 \mathrm{McF}$ arland standards. Dilutions of this suspension in $0.1 \%$ peptone $(\mathrm{w} / \mathrm{v})$ solution in sterile water is inoculated on LB agar, to check the viability of the preparations (Nair et al., 2005). 


\subsection{IN-SILICO MOLECULAR DOCKING}

Automated docking is used to determine the orientation of synthesized pyrazole compound binding with DNA. A genetic algorithm method is, implemented in the program Auto Dock 3.0, is employed (Bhat et al., 2003). The synthesized pyrazole compound is designed and the structure is analyzed by using ChemDraw Ultra 6.0. 3D coordinates are prepared using PRODRG server (Ghose et al., 1987). The DNA structure file 3GJH is taken from PDB (www.rcsb.org/pdb) is edited by removing the heteroatom (Binkowski et al., 2003).For docking calculations, Gasteiger Marsili partial charges are assigned to the ligands and nonpolar hydrogen atoms were merged. (Gasteiger et al., 1980).

All torsions are allowed to rotate during docking. The grid map is centered at the major groove and is adjusted such that it accommodated the major groove of the DNA duplex at the torsional degree of freedom 0.5 units. The genetic algorithm is applied for minimization, using default parameters. The number of docking runs is 50 , the population in the genetic algorithm is 250 , the number of energy evaluations is 100,000 , and the maximum number of interactions 10,000 .

\subsection{DNA INTERACTION EXPERIMENT (SPECTRAL MEASUREMENTS)}

UV-visible absorption spectra are determined in a SHIMADZU, UV-1650 PC recording spectro-photometer using quartz cuvettes of $10 \mathrm{~mm}$ light-path. The parameter of interaction between compound 4a with CT-DNA was determined spectro-photometrically by UV-visible spectrophotometer. Aliquots of a concentrated DNA solution $(0.25-1.125 \mu \mathrm{l})$ are added to a cuvette filled with $4 a$ solution $(12-25 \mu \mathrm{M})$ and thoroughly mixed. Extreme care is taken to ensure that optical reference solutions are prepared in an identical manner. The binding data expressed in the form of a Scatchard plot (Hollemans et al., 1975). The variables $r$ (moles of ligand bound/mole of nucleotides) and $C$ (the molar concentration of free drug) are calculated from the absorption measurements according to the method of Peacocke and Skerrett (Scott et al., 1998). The intrinsic binding constant $K_{b}$ and the maximum number of available binding sites/nucleotide $(\mathrm{n})$ are deduced from Scatchard plot.

Absorption: $\quad(D N A) /\left(\varepsilon_{a}-\varepsilon_{f}\right)=($ DNA $) /\left(\varepsilon_{b}-\varepsilon_{f}\right)+1 /\left(\varepsilon_{a}-\varepsilon_{f}\right)$

Where $\varepsilon_{\mathrm{a}}, \varepsilon_{\mathrm{f}}$ and $\varepsilon_{\mathrm{b}}$ are the apparent, free, and bound extinction coefficients at $298 \mathrm{~nm}$ for compound 4 a respectively. A plot of [DNA]/( $\left.\varepsilon_{b}-\varepsilon_{f}\right)$ versus [DNA] gave a slope of $1 /\left(\varepsilon_{b}-\varepsilon_{f}\right)$ and a $y$ intercept equal to $1 / K_{b}\left(\varepsilon_{b}-\varepsilon_{f}\right)$, where $K_{b}$ is the ratio of the slope to the $y$ intercept.

\subsection{VISCOSITY MEASUREMENTS}

Viscosity measurements are carried out by using a semi micro dilution capillary viscometer (Viscomatic Fica MgW) with a thermostated bath $\mathrm{D} 40 \mathrm{~S}$ at $20{ }^{\circ} \mathrm{C}$. For the viscosity experiments, samples of calf thymus DNA are sonicated (Baez et al., 1983) to fragments having an estimated molecular weight of approximately (Cohen 1969); (John et al., 1966).

\subsection{THERMAL DENATURATION EXPERIMENTS}

The DNA melting studies are done by controlling the temperature of the sample cell with a Shimadzu (SHIMADZU, UV-1650 PC) circulating bath while monitoring the absorbance at 
$260 \mathrm{~nm}$. The temperature of the solution is continuously monitored with a thermo-couple attached to the sample holder.

\subsection{DNA PHOTOCLEAVAGE STUDIES}

The extent of cleavage of super coiled (SC) pUC19 DNA $(0.5 \mathrm{ml}, 0.5 \mathrm{mg})$ to its nicked circular (NC) form is determined by agarose gel electrophoresis in Tris- $\mathrm{HCl}$ buffer $(50 \mathrm{mM}$, $\mathrm{pH}$ 7.2) containing $\mathrm{NaCl}(50 \mathrm{mM})$. In the cleavage reactions, the $40 \mathrm{mM}$ complexes in $18 \mathrm{ml}$ buffer are photo-irradiated using monochromatic UV or visible light for $1 \mathrm{~h}$ followed by addition to the loading buffer containing $25 \%$ bromophenol blue, $0.25 \%$ xylene cyanol, $30 \%$ glycerol $(3 \mathrm{ml}$ ) and finally loaded on $0.8 \%$ agarose gel containing $1.0 \mathrm{mg} / \mathrm{ml}$ ethidium bromide. Electrophoresis is carried out at $50 \mathrm{~V}$ for $3 \mathrm{~h}$ in Tris-borate EDTA (TBE) buffer. Bands are visualized by UV light and photographed to determine the extent of DNA cleavage from the intensities of the bands using UVITEC Gel Documentation System. Because of corrections are made for the trace of NC DNA present in the SC DNA sample and for the low affinity of EB binding to SC DNA in comparison to the NC form, the wavelength used for the photo-induced DNA cleavage experiments is $360 \mathrm{~nm}$ (Bhojya Naik et al., 2008).

\section{RESULTS AND DISCUSSION}

In the present study, a series of chalcones are prepared by condensing quinoline nucleus with 3-acetyl-derevatives 3(a-e) as shown in the (scheme-1). In the previous procedures (Badiadka Narayana et al., 2009) the condensations of reaction using $\mathrm{NaOH}$ or $\mathrm{KOH}$ as catalyst are used. In this procedure $\mathrm{K}_{2} \mathrm{CO}_{3}$ is used as mild base catalyst for the synthesis. The conversion of 2-chloro-3-formyl-quinoline to 2-mercapto and 2-seleno-3- formylquinoline is reported (Bhojya Naik et al., 2006, 2008). The compound 8-hydroxy quinoline and 2-napthol is formylated using Rieman-Tieman reaction (He-Ping Zeng et al., 2006) and it is cyclised (Bhojya Naik et al., 2006, 2008). The compounds 3(a-e) are converted in to pyrazole by condensing with hydrazine hydrate and refluxed for cyclization as shown in the (scheme-2). All newly synthesized compounds have confirmed by elemental analysis and spectroscopic methods like IR and ${ }^{1} H$ NMR and mass spectral data.

The synthesized chalcones $3(\mathrm{a}-\mathrm{e})$, showed the IR bands at $2850 \mathrm{~cm}^{-1}(\mathrm{C}-\mathrm{H} \mathrm{str})$, at $1610 \mathrm{~cm}^{-1}$ $(\mathrm{C}=\mathrm{N}), 3610 \mathrm{~cm}^{-1}(\mathrm{Ar}-\mathrm{OH}),-\mathrm{NH}$ at $3420 \mathrm{~cm}^{-1}$ and $1580,1540,1470 \mathrm{~cm}^{-1}$ of $(\mathrm{Ar}-\mathrm{C}=\mathrm{C})$ whereas in ${ }^{1} \mathrm{H}-\mathrm{NMR}$ the 6.4 signal showed doublet peak of proton $(-\mathrm{CO}-\mathrm{CH}=)$, at 7.4 doublet signal of $(=\mathrm{CH}-\mathrm{Ar})$, at $7.5-8.3$ multiplet signals of aromatic protons.

In compound 4(a-e), the IR band showed at $3336.9 \mathrm{~cm}^{-1}$ of $(\mathrm{C}-\mathrm{NH})$ stretching, at $2850 \mathrm{~cm}^{-1}$ peak corresponds to $\left(\mathrm{C}-\mathrm{H}\right.$ str), at $1640 \mathrm{~cm}^{-1}$ corresponds to $(\mathrm{C}=\mathrm{O})$, at $1610 \mathrm{~cm}^{-1} \quad(\mathrm{C}=\mathrm{N})$ stretching ,at 1580,1540,1470 cm $\mathrm{cm}^{-1}$ showed (Ar-C=C str), at $1032.8 \mathrm{~cm}^{-1}$ showed (C-N) stretching and $640.5 \mathrm{~cm}^{-1}$ showed $(\mathrm{C}-\mathrm{Cl})$ stretching. The ${ }^{1} \mathrm{H}-\mathrm{NMR}$ signals at 6.2 doublet peak of proton $(-\mathrm{CH}=)$, the multiplet of aromatic protons at $7.4-8.05$, the signal at 8.6 singlet of aromatic proton, at 13.5 broad singlet of $-\mathrm{NH}$ proton. The rest of the aromatic protons appeared in the usual region. Molecular ion $[\mathrm{M}+\mathrm{H}]^{+}$peak of compound $4(\mathrm{a}-\mathrm{e})$ are observed at different intensities in positive ionization mode and confirmed the molecular weights.

Compound which has halogen atoms in their molecule showed characteristic peaks in their mass spectrum analogous to isotopic distribution $\left({ }^{35} \mathrm{Cl}\right.$ and ${ }^{37} \mathrm{Cl}$ isotopes). 


\subsection{SCHEME 1}

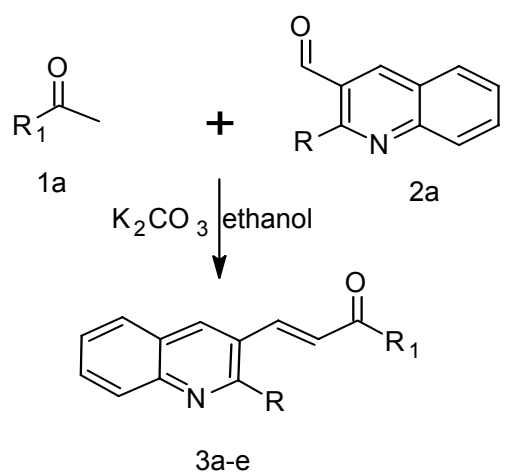

$\mathrm{R}=\mathrm{Cl}$ and $\mathrm{OH}$

$\mathrm{R}_{1}=$ substituted acetyl compounds

\subsection{SCHEME 2}

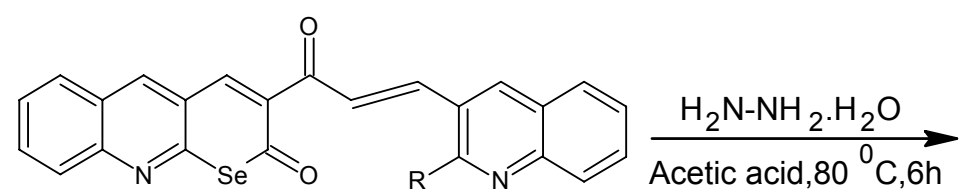

$3(a-e)$

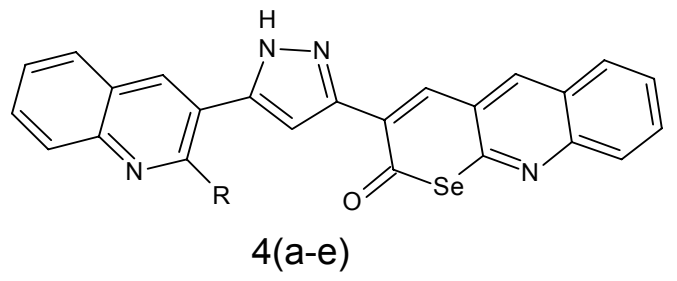

$\mathrm{R}=\mathrm{Cl} / \mathrm{OH}$ 
British Journal of Pharmaceutical Research, 1(2): 46-65, 2011

Table 1. The chalcones using different acetyl group compounds, Product, Yield and melting point of the compound

\begin{tabular}{|c|c|c|c|c|c|}
\hline $\begin{array}{l}\text { SI. } \\
\text { No. }\end{array}$ & Compound $=\mathbf{R}_{\mathbf{1}}$ & $\mathbf{R}$ & Product & $\begin{array}{c}\text { Yield } \\
\%\end{array}$ & $\begin{array}{l}\text { Melting } \\
\text { Point } \\
\left({ }^{\circ} \mathrm{C}\right)\end{array}$ \\
\hline $3 a$ & & $\mathrm{Cl}$ & & 84 & $180-182$ \\
\hline $3 b$ & & $\mathrm{Cl}$ & & 76 & $146-148$ \\
\hline $3 c$ & & $\mathrm{OH}$ & & 79 & $132-134$ \\
\hline $3 d$ & & $\mathrm{Cl}$ & & 69 & $128-130$ \\
\hline $3 e$ & & $\mathrm{Cl}$ & & 81 & $118-120$ \\
\hline
\end{tabular}


Table 2. The Pyrazole using different chalcones, Yield and melting point of the compound

\begin{tabular}{|c|c|c|c|c|c|}
\hline $\begin{array}{l}\text { Sl. } \\
\text { No. }\end{array}$ & $\begin{array}{c}\text { Chalcones } \\
(3 a-e)\end{array}$ & $\mathbf{R}$ & Pyrazoles & Yield\% & $\begin{array}{c}\text { Melting } \\
\text { Point }{ }^{0}(\mathrm{c})\end{array}$ \\
\hline $4 a$ & & Cl & & 78 & $166-168$ \\
\hline $4 b$ & & $\mathrm{Cl}$ & & 68 & $110-112$ \\
\hline $4 c$ & & $\mathrm{OH}$ & & 70 & $120-122$ \\
\hline $4 d$ & & $\mathrm{Cl}$ & & 74 & $114-116$ \\
\hline $4 e$ & & $\mathrm{Cl}$ & & 72 & $106-108$ \\
\hline
\end{tabular}




\subsection{ANTIBACTERIAL ACTIVITY}

The minimum inhibitory concentrations (MICs) of the newly synthesized compound $4 \mathrm{a}, 4 \mathrm{~b}$ and standard ciprofloxacin against all bacterial strains are as shown in Table 4. The significant MIC value is obtained for Staphylococcus aureus, $10 \mathrm{mg} / \mathrm{mL}$ for compound $4 \mathrm{a}$ and $7 \mathrm{mg} / \mathrm{mL}$ for compound $4 \mathrm{~b}$. Comparison of results of the antibacterial activity between newly synthesized compounds $4 \mathrm{a}$ and $4 \mathrm{~b}$ and ciprofloxacin showed a synchronizing effect on strains of pathogenic bacteria. The zones of inhibition of the bacterial colony are depicted in Table 3. Compound 4a demonstrated antibacterial activity against all the strains of bacteria. But it is significant on Gram-positive bacteria Staphylococcus aureus $(17.60 \mathrm{~mm})$ and Streptococcus pyogenes $(17.40 \mathrm{~mm})$.

Among the newly synthesized compounds, compound 4 a containing selenium component proved to be a more potent bactericidal agent against $\mathrm{S}$. aureus $(17.60 \mathrm{~mm})$ and Bacillus subtilis - NCIM- $2010(17.10 \mathrm{~mm})$. Compound 4b containing sulfur showed a meager antimicrobial property against all the pathogenic strains of bacteria (Figure.1).
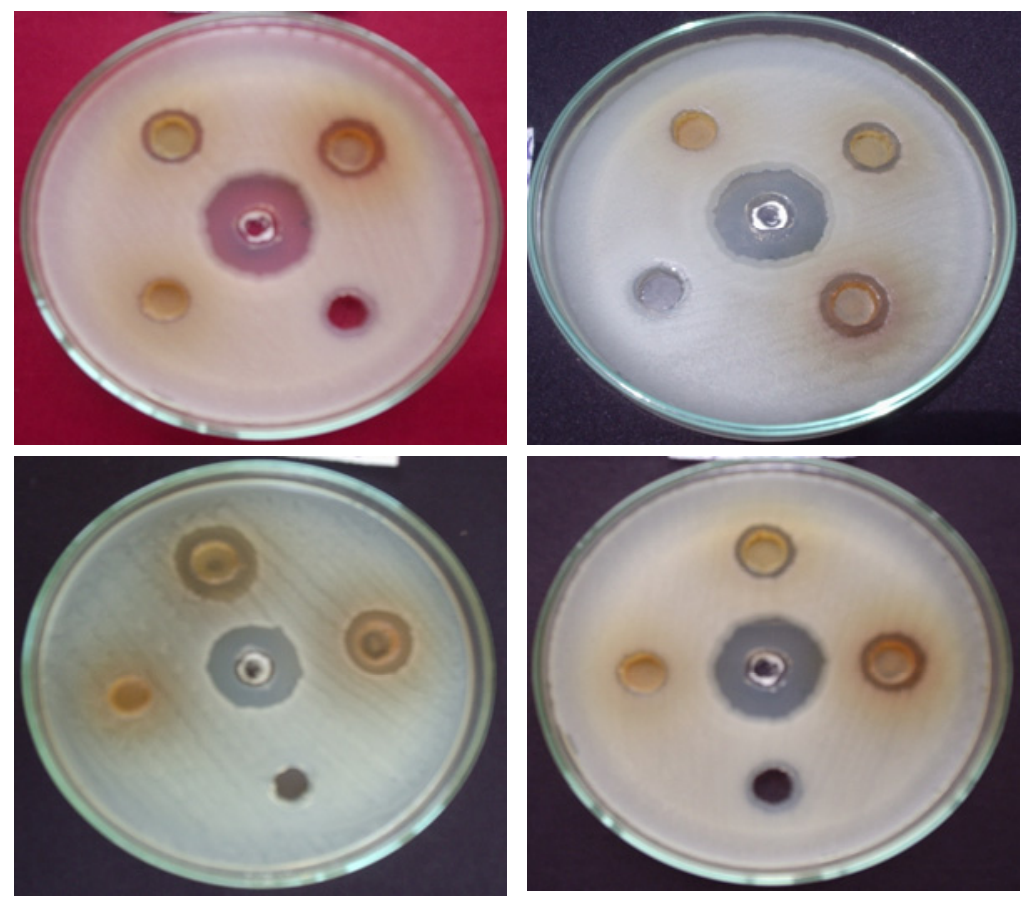

Fig. 1. Antibacterial activity of compound 4. A: zone of inhibition for Staphylococcus aureus; B: zone of inhibition for Bacillus subtilis; C: zone of inhibition for Streptococcus pyogenes; D: zone of inhibition for Pseudomonas aeruginosa.

The results obtained in this study indicate a considerable difference in antibacterial activity among the two newly synthesized compounds. Compound 4a containing selenium exhibited significant antibacterial activity against pathogenic bacterial strains. Its bio-controlling potency is per with that of the standard antibiotic ciprofloxacin. Generally, the Gram-positive bacteria are more susceptible having only an outer peptidoglycan layer which is not an effective permeability barrier (Scherrer et al., 1971). Whereas the Gram-negative bacteria 
possess an outer phospholipidic membrane carrying the structural lipo-polysaccharide components. This makes the cell wall impermeable to drug constituents (Betoni et al., 2006).

Table 3. Antibacterial activity of the synthesized compounds against pathogenic bacterial strains

\begin{tabular}{l|llc}
\hline \multirow{2}{*}{ Clinical strains } & \multicolumn{3}{c}{ Diameter of zone of inhibition (mm) } \\
\cline { 2 - 4 } & Compound 4a & Compound 4b & Ciproflaxin \\
\hline Streptococcus pyogenes & $17.40 \pm 0.10$ & $14.10 \pm 0.10$ & $22.60 \pm 0.10$ \\
Staphylococcus aureus & $17.60 \pm 0.10$ & $14.90 \pm 0.10$ & $23.80 \pm 0.10$ \\
Pseudomonas aeruginosa & $16.40 \pm 0.10$ & $15.60 \pm 0.10$ & $22.20 \pm 0.10$ \\
Bacillus subtillis & $16.10 \pm 0.10$ & $15.90 \pm 0.10$ & $21.10 \pm 0.10$ \\
\end{tabular}

So the maximum inhibitory activity is observed in Gram-positive bacteria Staphylococcus aureus. In the case of Gram-negative Pseudomonas aeruginosa the zone of inhibitory activity is significant because of a multilayered phospholipidic membrane carrying the structural lipo-polysaccharide components (Nikaido 1985). Selenium containing compound $4 a$ showed maximum inhibition zones compared to that of sulfur containing compound $4 \mathrm{~b}$. Thus, compound $4 a$ is effective in controlling the growth of pathogenic strains to a considerable extent. The highest activity of compound $4 a$, when compared to that of compound $4 \mathrm{~b}$, indicated that it is solely responsible for antibacterial activity.

Table 4. MIC $(\mathrm{mg} / \mathrm{mL})$ values of synthesized compounds $4 \mathrm{a}$ and $4 \mathrm{~b}$

\begin{tabular}{lccc}
\hline \multicolumn{4}{c}{ Bacterial strains Minimum inhibitory concentrations (MIC) } \\
\hline Compounds & 4a & 4b & Ciprofloxacin \\
\hline Streptococcus pyogenes & 11.5 & 11.5 & 6.35 \\
Staphylococcus aureus & 10.0 & 7.0 & 6.85 \\
Pseudomonas aeruginosa & 12.0 & 12.9 & 6.35 \\
Bacillus subtilis & 12.25 & 12.2 & 7.50 \\
\hline
\end{tabular}

\subsection{IN-SILICO MOLECULAR DOCKING}

Careful examination of B-DNA structures reveals the reason for the difference in the positioning in the two helical forms. The predicted binding of ligands to the DNA bases on the basis of the clustering of Cartesian coordinates is thus more directional than that expected from the ellipsoids derived from Fourier averaging. Calculation of the energy of a drug-DNA system entails the enumeration of a set of critical atoms on the drug that may interact with the ligand-binding sites around the DNA bases. Each of the potential hydrogen bond donor or acceptor atoms on the drug is assigned a DNA-binding ellipsoid with complementary acceptor or donor properties.

The partner ellipsoid is selected on the basis of the magnitude of interaction with the drug atom, i.e., the interaction score of lowest value. The number of interactions with DNA is limited by the hydrogen-bonding quotas of the unfulfilled proton donor and acceptor sites on the edges of the Watson-Crick base pairs.

Since an atomic-resolution structure of newly synthesized compounds bound to DNA is not yet available, there is no much experimental evidence regarding the orientation and binding 
modes of parent compounds $4 \mathrm{a}$ when it is bound at the major groove. According to two criteria, prediction statistics and energy ranking, docking of pyrazole to DNA results in both energetically favorable binding mode and binding site Figure 2.
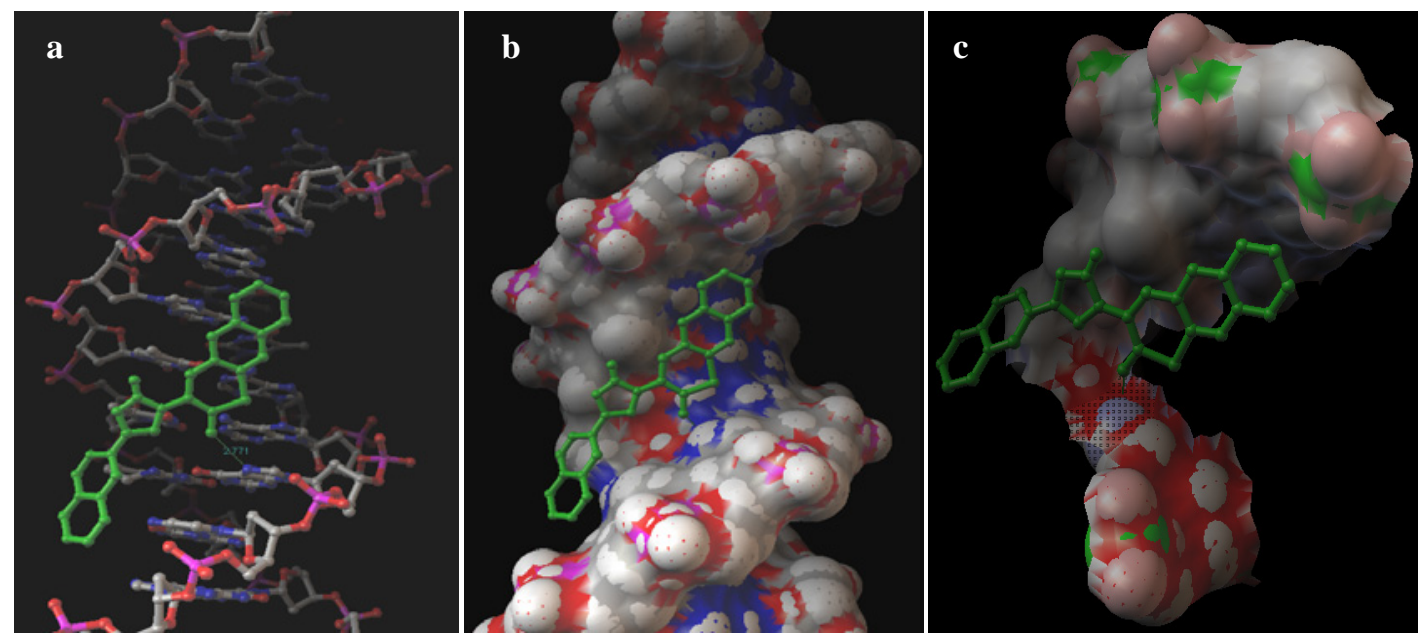

Fig. 2. (a) Ball and Stick of DNA with the compound (4a) (green ball and stick) and showing the hydrogen bond formation with bond length. (b) The synthesized compound (green ball and stick) is enfolded in the major groove of DNA showing interacting with chain $A$ and chain $B$ (MSMS-MOL). (c) Hydrogen bond between the compound(4a) (stick and ball colored by green) and the N7 (DG16) residue of chain $B$ of DNA and interacting with residues DA5, DA6, DT7, DT8, B7C9 of chain A and DG16 of chain $B$.

In-silico molecular docking of compound 4a with the DNA revealed that the docked energy for the compound is -8.66 with an estimated binding energy of -8.62 ( $\AA$ units), intermolecular energy -8.93. The synthesized compound is completely enfolded in the entire major groove of DNA (Figure 1b). However, orientation of synthesized molecule is perpendicular to the plane made by DA5, DA6, DT7, DT8, B7C9 of chain A and DG16 of chain B (Figure 1c). The compound 4 a showed efficient binding at major groove than minor groove and inhibition constant $\left(7.46 \times \mathrm{X}^{-6}\right)$. The Grid is adjusted such that it accommodated the major groove of the DNA duplex at the torsional degree of freedom 0.5 units and is docked using genetic algorithm. The compound (4a) hydrogen bonded with the backbone hydrogen of DG16 with a bond distance of 2.771 with internal energy of 0.27 and torsional energy of 0.31 (Figure1a).

\subsection{DNA BINDING STUDIES}

Primarily, the DNA binding is observed by the following parameters:

(i) electrostatic interactions with the negative charged nucleic sugar-phosphate structure which are along the external DNA double helix and do not possess selectivity

(ii) binding interactions with two grooves of DNA double helix; and

(iii) intercalation between the stacked base pairs of native DNA (Fairley et al., 1993; Gopal et al., 2002). 
In comparison of compound 4(a-e), the compound 4a shows good results for both DNA binding cleavage studies compared to other compounds. The interaction of $4 a$ with DNA resulted in the decrease of absorption intensity accompanied by a shift towards higher wavelengths from $298 \mathrm{~nm}$. The addition of increasing higher concentration of DNA led to hypochromic and bathochromic (red shift) changes in its visible absorption spectra.

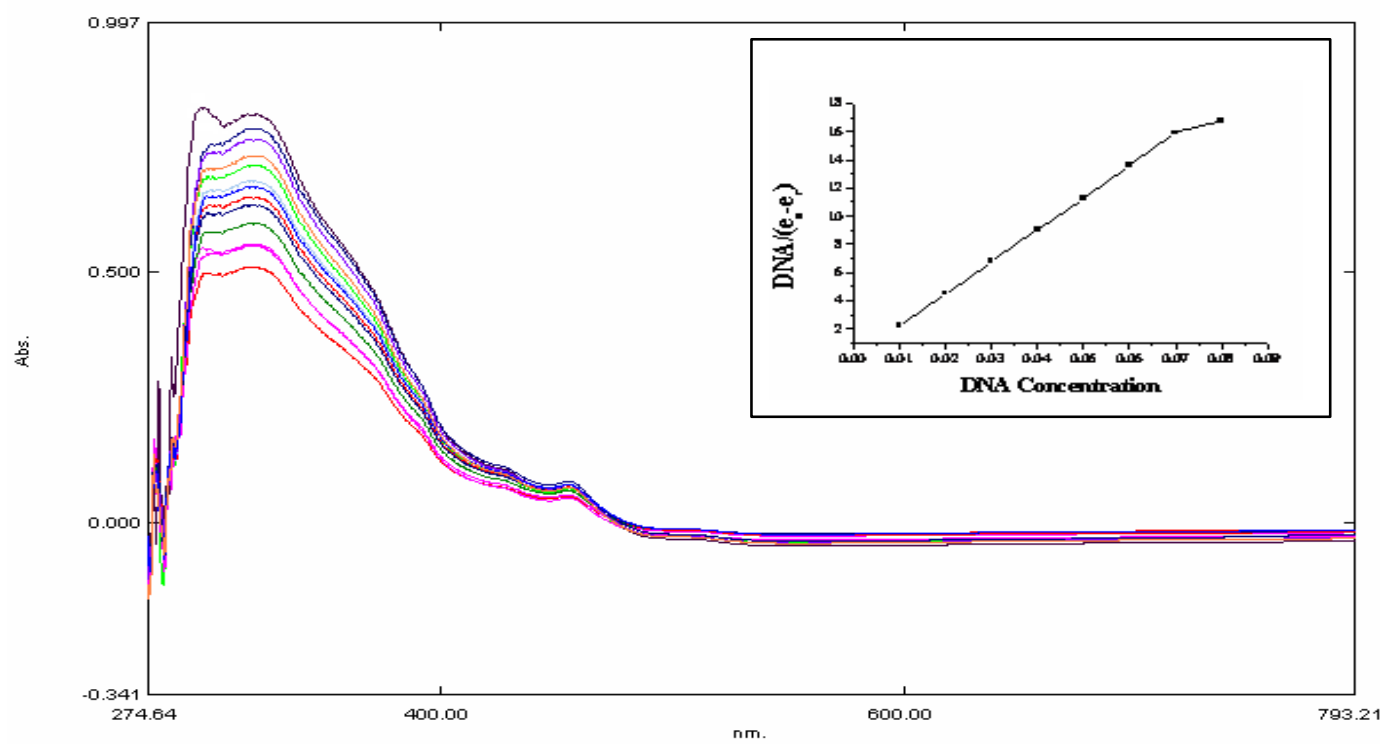

Fig. 3. Absorption spectra of pyrazole in Tris- $\mathrm{HCl}$ buffer upon addition of DNA: $=0.5 \mu \mathrm{M}$, $[\mathrm{DNA}]=0-100 \mu \mathrm{M}$. Showing variation in absorption with increase in concentration of [DNA].Inner plot of [DNA]/ ( $\varepsilon a-\varepsilon f)$ versus [DNA] for titration of DNA.

The DNA binding studies are characterized by absorbance maxima at $298 \mathrm{~nm}$ for quinoline Pyrazole (4a). Around 5-8\% reduction (hypo-chromism) of absorption is observed at $298 \mathrm{~nm}$ peak maximum in the presence of an excess of calf thymus DNA. The lowest observation value observed in spectral changes (including red shift and hypochromicity) are used to evaluate intrinsic binding constant $\left(K_{\mathrm{b}}\right)$, it observed $4.5 \times 10^{-4} \mathrm{M}^{-1}$ which are consistent with the intercalation of (4a) with DNA base pairs (Wolfe et al., 1987); (Devappa et al., 2008).

\subsection{VISCOSITY MEASUREMENTS}

To further clarify, the interaction modes of the compounds 4a with DNA are investigated by viscosity measurements. An increase in viscosity of native DNA is regarded as a diagnostic feature of an intercalation process (Maiti et al., 1984); (Kunes et al., 2001). We have measured the viscosity changes in short, rod like DNA fragments.

The relative length increase $(L / L O)$ of the complex formed between 4a with DNA is shown in Figure (4). It is evident that binding of these compounds increases the viscosity of DNA corresponding to an increase in the contour length of the DNA fragments.

The measured slopes of the plots $1.23 \pm 0.03$, for compound 4 a falls within $63 \%$ of the slope of a theoretical curve for an idealized intercalation process $(1+2 r)$ (Patel et al., 1979). 


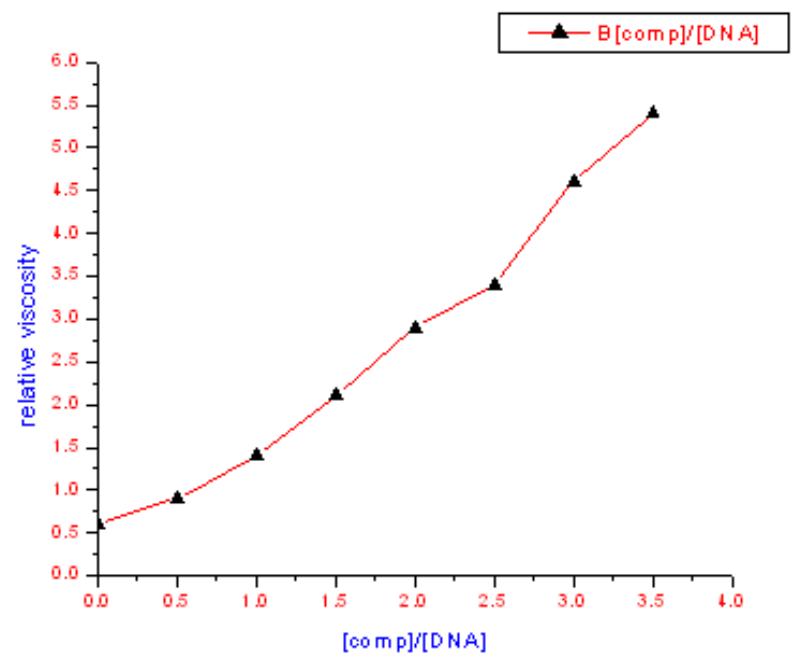

Fig. 4. Plot shows effect of $4 \mathrm{a}$ on the viscosity of CT-DNA at $25\left( \pm 0.1^{\circ} \mathrm{C}\right)$. $4 \mathrm{a}=0-100 \mu \mathrm{M}$ and $[\mathrm{DNA}]=50 \mu \mathrm{M}$

On this basis, we calculated that intercalation of $4 \mathrm{a}$ molecule provoked an increase of $1.9^{0} \mathrm{~A}$ in the contour length of DNA. Since the size of these sonicated fragments is significantly greater than the persistence length, the estimated $1.9 \mathrm{~A}^{0}$ lengthening is probably best regarded as a lower limit.

\subsection{THERMAL DENATURATION}

Other strong evidence for the intercalative binding of compounds into the double helix DNA is obtained from DNA melting studies. The intercalation of small molecules into the double helix is known to increase the DNA melting temperature $(T m)$, at which the double helix denatures into single stranded DNA owing to the increased stability of the helix in the presence of an intercalator (Zuby 1988).

The molar extinction coefficient of DNA bases at $260 \mathrm{~nm}$ in the double helical form is much lesser than the single stranded form. Hence, melting of the helix leads to an increase in the absorbance at $298 \mathrm{~nm}$. Thus, the helix to coil transition temperature can be determined by monitoring the absorbance of DNA at $298 \mathrm{~nm}$ as a function of temperature (Maguire et al., 1994). The DNA melting studies are carried out with calf thymus DNA in the absence and presence of $4 a$ [1: 3 ratio of $4 a$ to DNA-c(P)]. The Tm for calf thymus DNA was $60 \pm 5^{\circ} \mathrm{C}$. These DNA melting experiments strongly supported the intercalation of $4 a$ into the double helix DNA (Figure. 5). 


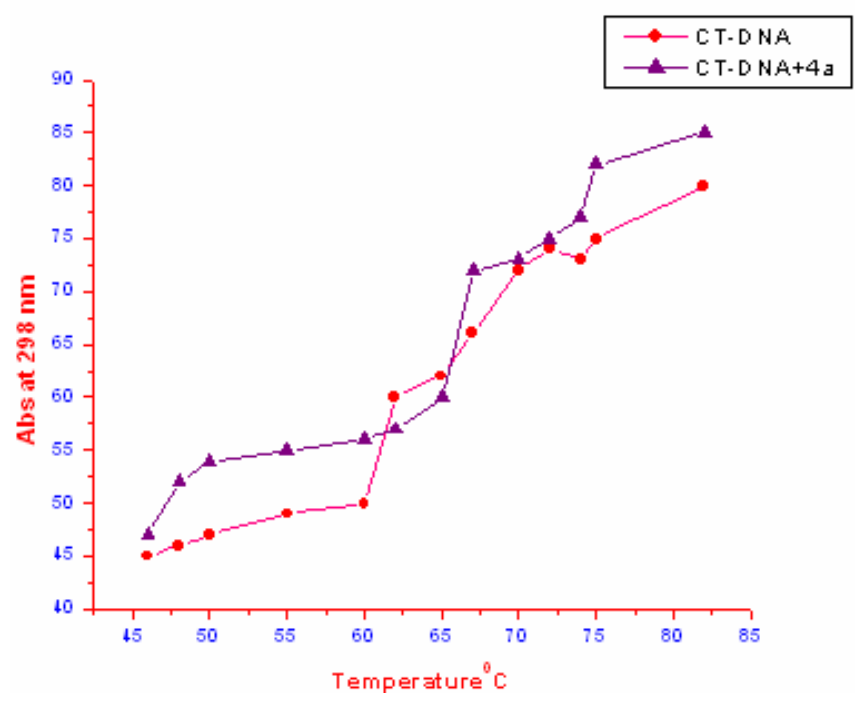

Fig. 5. Melting curves of CT-DNA in absence and presence of compounds $4 \mathrm{a}$ in the absence of compounds, but in the presence of parent compound (4a) the Tm of CT DNA were increased by $5^{\circ} \mathrm{C}$.

\subsection{THE PUC 19 DNA PHOTO CLEAVAGE STUDIES}

It is now recognized that the extremely reactive $\mathrm{OH}$ radical derived from $\mathrm{O}_{2}^{-}$and $\mathrm{H}_{2} \mathrm{O}_{2}$ is a cause of DNA strand scission in cellular damage. Figure 6 shows the electrophoresis pattern of DNA after UV-photolysis of $\mathrm{H}_{2} \mathrm{O}_{2}(2.5 \mu \mathrm{mol} / \mathrm{L})$ in the absence or presence of the compound. The faster-moving band corresponding to the native form of supercoiled circular DNA (SCDNA) and the slower-moving band being the open circular form (OC-DNA) (Bhojya Naik et al., 2008). The UV irradiation of DNA in the presence of $\mathrm{H}_{2} \mathrm{O}_{2}$ (lane 2) caused the cleavage of SC-DNA to give open coiled DNA (OC-DNA) and the linear form (lin-DNA) in lane 5 and 7 , indicating that $\cdot \mathrm{OH}$ generated by UV-photolysis of $\mathrm{H}_{2} \mathrm{O}_{2}$ produced DNA strand scission. The presence of the compound under investigation increases the DNA damage which has been particularly implicated in carcinogenesis.

We found that the supercoiled DNA (form I) is cleaved by lane 6 only after 45 min and $1 \mathrm{hr}$. In order to clarify the DNA cleavage mechanism, compound was investigated in the presence of chelating agent. The compounds are tested for DNA cleavage under hydrolytic conditions, and a concentration dependent cleavage is observed. Reaction that leads to formation of open circular DNA (form II) from the supercoiled (form I) over various concentrations of compound $4 \mathrm{a}(100-500 \mu \mathrm{M} / \mathrm{L})$ and constant DNA concentration is followed for different concentration at $37^{\circ} \mathrm{C}$ (Figure 6). 


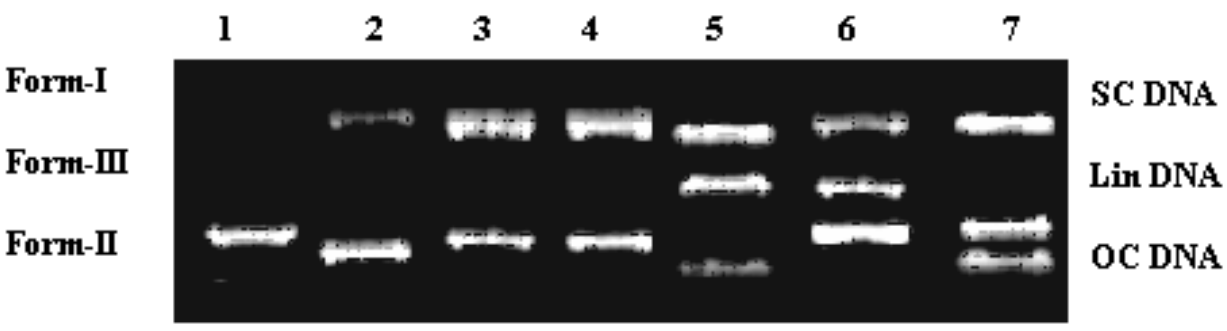

Fig. 6. Effects of 6 at various concentrations $(100-600 \mu \mathrm{mol} / \mathrm{L})$ on the $\mathrm{pUC} 19$ supercoiled DNA against $\mathrm{OH}$ generated by photolysis at $360 \mathrm{~nm}$ in presence of $\mathrm{H}_{2} \mathrm{O}_{2}$. Lane 1, Untreated DNA (control); lane 2, DNA + $\mathrm{H}_{2} \mathrm{O}_{2}$; lane 3, DNA + 4a $(100 \mu \mathrm{mol} / \mathrm{L})$;

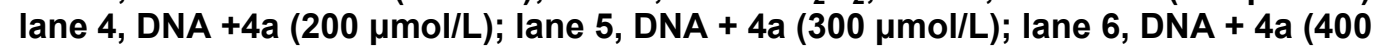
$\mu \mathrm{mol} / \mathrm{L})$; lane 7, DNA + 4a (500 $\mu \mathrm{mol} / \mathrm{L})$.

\section{CONCLUSION}

We developed a versatile and useful new access to different scaffold of biologically important newly synthesized pyrazoles. The selenium containing pyrazole showed significant zone and minimum inhibitory concentration in antibacterial activity over sulfur containing compound. In-silico molecular docking studies revealed that can efficiently bind to DNA with significant docking and binding energy.

The DNA binding showed intercalative mode of binding in the base pair of DNA. The compounds have been found to cleave plasmid pUC19 DNA from the supercoiled Form I to the nicked circular Form II upon $\mathrm{H}_{2} \mathrm{O}_{2}$ activation, where as in photocleavage studies these compounds in the absence of "inhibitors" shows more cleavage properties, which may taken as these compounds are potential DNA cleaving agents. Therefore, it is suggested that further work could be performed on similar heterocyclic pyrazole analogues. By this we can conclude that our newly synthesized compound has importance in medicinal/ biological field.

\section{ACKNOWLEDGEMENT}

We thank to Kuvempu University for providing JRF, UGC for providing project ref.no.F.33$322 / 2007$, Indian Institute of Science, Bangalore, for providing spectral data and University of Mysore, for providing elemental analysis facility.

\section{REFERENCES}

Adnan, A. Bekhit., Tarek., Abdel-Aziem., et.al. (2004). Design, synthesis and biological evaluation of some pyrazole derivatives as anti-inflammatory-antimicrobial agents. Bioorganic \& Medicinal Chemistry. 12, 1935-1945.

Aglawe, M. J., Dhule, S. S., Bahekar, S. S., Wakte, P.S., et.al. (2003). Synthesis and Antibacterial Activity of Some Oxazolone Derivatives. J. Korean .Chem. Soc., 47, 02.

Angell, Y., Burgess, K., (2005). Ring Closure to $\beta$-Turn Mimics via Copper-Catalyzed Azide/Alkyne Cycloadditions. J. Org. Chem., 70, 9595. 
Argade, N. D., Gill, C. H., et.al. (2008). Microwave Assisted Improved Method for the Synthesis of Pyrazole Containing 2, 4,-Disubstituted Oxazole-5-one and their Antimicrobial Activity. E-Journal of Chemistry. 5, 1, 120-129.

Baez, A., Gonzalez, F.A., Vazquez, D., Waring, M. et.al. (1983). Interaction between A 3nitrobenzothiazolo $(3,2-a)$ quinolinium antitumour drug and deoxyribonucleic acid. Biochem. Pharmacol. 32, 2089-2094.

Barbachyn, M. R., Brickner, S. J., Cleek, G. J., et.al. (1997). In Anti-infectives: Recent Advances in Chemistry and Structure-activity Relationships; Bentley, P. H., O'Hanlon, P. J., Eds.; The Royal Society of Chemistry, 15.

Benedetti, D.V. and Daniel, L., et.al. (1994). Synthesis of 2-Methyl-(Z)-4-(phenylimino) naphtha- [2,3-d] oxazol-9-one, a Monoimine Quinone with Selective Cytotoxicity toward Cancer Cells. J.Med. Chem, 37, 710.

Betoni, J.E.C., Mantovani, R.P., Barbosa, L.N., et.al. (2006).Synergism between plant extract and antimicrobial drugs used on Staphylococcus aureus diseases. Memo' rias do Instituto Oswaldo, Rio de Janeiro., 101, 387-390.

Bhat, R., Xue, Y., Berg, S., et. al. (2003). Structural Insights and Biological Effects of Glycogen Synthase Kinase 3- specific Inhibitor AR-A014418. J. Biol. Chem., 278, 45937-45945.

Binkowski, T. A., Naghibzadeg, et.al. (2003). CAST (computed atlas of surface topography) of proteins. Nucleic Acid Res., 31, 3352-3355.

Brickner, S.J. (1996). Oxazolidinone antibacterial agents. Curr Pharm Design, 2, 175.

Chen, L., Fang, K.C., Sheu, J.Y., et.al. (2001). Synthesis and Antibacterial Evaluation of Certain Quinolone Derivatives. J. Med. Chem., 44, 2374-2377.

Cohen, G., (1969). Eisenberg, H. Viscosity and sedimentation study of sonicated DNAproflavine complexes. Biopolymers, 8, 45- 55.

Cohen, M.L. (2000). Changing patterns of infectious disease. Nature, 406, 762.

Desai, N.C., Dave,D., Shah, M. D., Vyas, G.D., et.al. (2000). Synthesis and antibacterial activity of some novel 4-oxo-1,3-thiazolidines, 2-oxoazetidines and 5-oxoimidazolines. Indian J Chem, 39(B):277-82.

Devappa. S. Lamani., Venugopala Reddy K. R ., Bhojya Naik. H. S.,et.al. (2008). Synthesis and DNA Binding Studies of Novel Heterocyclic Substituted Quinoline Schiff Bases: A Potent Antimicrobial Agent. Nucleosides, Nucleotides and Nucleic Acids, 27, 11971210.

Fairley, T.A., Tidwell, R.R., Cory, M. J., et.al. (1993). Synthesis and Antibacterial Evaluation of Certain Quinolone Derivatives. J. med.Chem. 36, 1746-1753.

Fisher, C., Schofield, J.B. (1991). S-100 protein positive synovial Sarcoma.Histopathology. 19, 375-377.

Gasteiger, J., Marsili, M., et.al. (1980). Iterative partial equalization of orbital electronegativity - a rapid access to atomic charges. Tetrahedron. 36, 3219-3288.

Gatto, B., Capranico, G., Palumbo, M., et.al. (1999). Drugs acting on DNA topoisomerases:

recent advances and future perspectives. Curr. Pharmacol. Design. 5, 195.

Ghose, A. K., Crippen, G. M., et.al. (1987). Atomic physicochemical parameters for threedimensional-structure-directed quantitative structure-activity relationships. 2. Modeling dispersive and hydrophobic interactions. J. Chem. Inform. Comput. Sci., 27, 21.

Gopal, M., Shahabuddin, M.S., et.al. (2002). Interaction between an 8-methoxy pyrimido $\left[4^{\prime}, 5^{\prime}: 4,5\right]$ thieno $(2,3-b)$ quinoline-4(3H)one antitumour drug and deoxyribonucleic acid Indian Acad Sci (Chem Sci).114, 687-696.

Halehatty, R, Prakash Naik., Halehatty. S. Bhojya Naik., Thangali. R. Ravikumar Naik., et.al. (2009). Synthesis of novel benzo[h]quinolines: Wound healing, antibacterial, DNA binding and in vitro antioxidant activity. Eur. Jour. of Med Chem., 44, 981-989. 
He-Ping Zeng., Xin-Hua OuYang., et.al., (2006). Synthesis, Crystal Structure, and Prediction of Hole Mobilities of 2,7'-Ethylenebis(8-Hydroxy quinoline) Crystal Growth \& Design. 6, (7), 1697-1702.

Hollemans, H. J. G., Bertina, R. M., et.al. (1975). Scatchard Plot and Heterogeneity in Binding Affinity of Labeled and Unlabeled Ligand. Clinical Chemistry. 21: 1769-1773.

Howell, S. J., Philp, D., et.al., (2001). Recognition-mediated regiocontrol of a dipolar cycloaddition reaction. Tetrahedron, 57, 4945.

John, M., Peterson, W.R., et.al. (1966). A differential solvent effect on thermal stability of genetic markers in DNA. J. Mol. Biol., 20, 497-503.

Klayman, D.L., Guther W.H. (Eds.). (1973). Organic Selenium Compounds: Their Chemistry and Biology, John Wiley and Sons, Inc, New York.

Kunes, J., Balsanek, V., Pour, M., et.al. (2001). Synthesis and Antifungal Activity Evaluation of 3-Hetaryl-2,5-dihydrofuran-2-ones. An Unusual Fragmentation of the Oxazole Ring via 2,3-Selenoxide. Shift Czechoslovak Chemical.Communications Abstracts, 66(12), 1809-1830.

Laure, L., Christian, R., Gabriel, M.,et.al. (1988). A new series of ellipticine derivatives (1(alkylamino)-9- methoxyellipticine). Synthesis, DNA binding, and biological properties. J. Med. Chem., 31, 1951-56.

Loaiza-Rodriguez, P., Quintero, A., et.al. (2004). Synthesis and evaluation of 9-anilino thiazolo-[5,4-b] quinoline derivatives as potential antitumorals. Eur. J. Med. Chem. 39, $5-10$.

Lunzer, M. M., Philip, S. P. (2007). Naloxone acts as a potent analgesic in transgenic mouse models of sickle cell anemia. 104, 14, 6061-6065.

Maekawa, T., Sakai, N., et.al. (2003). Synthesis and biological activity of novel 5-(omegaaryloxyalkyl) oxazole derivatives as brain-derived neurotrophic factor inducers. Che Pharm Bull (Tokyo). 51(5), 565-573.

Maguire, M.P., Sheets, K.R., Mc.Vety, K., et.al. (1994). A New Series of PDGF Receptor Tyrosine Kinase Inhibitors: 3-Substituted Quinoline Derivatives. J. Med. Chem., 37, $2129-2137$.

Maiti, M., Nandi, R., Chauduri, K.(1984). A study of thermal denaturation/ renaturation in DNA using laser light scattering: A new approach. Indian. J. Biochem. Biophys., 21, 158-162.

Mokle, S.S, Khansole, S.V., Patil, R.B., et.al. (2010). Synthesis and antibacterial activity of some new chalcones and flavones having 2-chloro-8-methoxyquinolinyl moiety. International Journal of Pharma and Bio Sciences. Med.Chem. 1(1)2010.

Nair, R., Kalariya, T., Chanda, S., et.al. (2005). Antibacterial activity of some selected Indian medicinal flora. Turk. J. Biol. 29, 41-47.

Nandeshwarappa, B.P., Bhojya Naik, H.S., Arun kumar., et.al. (2006). Microwave Assisted Synthesis of Some Novel Thiopyrano [2, 3-b] quinolines as a New Class of Antimicrobial Agent. Phosphorus, Sulfur and silicon., 181:1545-1556.

Nikaido,V., (1985). Molecular basis of bacterial outer membrane permeability. Microbiol. Rev.1., 1-32.

Patel, D.J., (1979). Nuclear magnetic resonance studies of drug-nucleic acid interactions at the synthetic DNA level in solution. Acc. Chem. Res., 12, 118-125.

Prabhakara, M.C., Bhojya Naik, H.S., et.al. (2008). Mixed ligand Ni (II) complexes: DNA binding, oxidative and photo-cleavage studies. Main Group Chemistry. 7, 2, 97-107.

Roma, G., Braccio, M.D., Grossi, G.,et.al. (2000). 1,8-Naphthyridines IV. 9-Substituted N,Ndialkyl-5-(alkylamino) [1,2,4]triazolo[4,3-a] [1,8] naphthyridine -6-carbox -amides, new compounds with anti-aggressive and potent anti-inflammatory activities. Eur. J. Med.Chem. 35, 1021-1035. 
Raghavendra, M., Bhojya Naik, H. S., Sherigara,B.S., et.al. (2008). A Facile One-Pot, Microwave Assisted Synthesis of Some Novel Selenolopyrano[2,3-b]quinolines under Microwave Irradiation Conditions. Phosphorus, Sulfur, and Silicon. 183, 2086-2094.

Sao Paulo., De Moura., Kelly C. G., et.al. (2001). Trypanocidal activity of isolated naphthaquinones from Tabebuia and some heterocyclic derivatives: a review from an interdisciplinary study. J. Braz. Chem. Soc.12, 3.

Scherrer, R., Gerhardt, P., et.al. (1971). Porosity of the Yeast Cell Wall and Membrane. J.Bacteriol. 107, 718- 735.

Scott, R. Rajski., Robert, M .Williams., et.al. (1998). DNA Interstrand Cross-Linking Agents as Anti -tumor Drugs. Chemical Reviews. 98 (8), 2723-2796.

Shinabarger, D.A., (1999). Mechanism of action of the oxazolidinone antibacterial agents. Exp Opin Invest Drugs. 8, 1195-1202.

Tornoe, C. W., Christensen, C., Meldal, M., et.al. (2002). Peptidotriazoles on Solid Phase:[1,2,3]-Triazoles by Regiospecific Copper(I)-Catalyzed 1,3-Dipolar Cycloadditions of Terminal Alkynes to Azides J. Org.Chem., 67, 3057; Aravinda, T., Bhojya Naik, H. S. prakash Naik., et.al. (2009). 1,2,3-Triazole Fused QuinolinePeptidomimetics: Studies on Synthesis, DNA Binding and Photonuclease Activity. Int. J. Pept. Res. Ther. 15, 273-279.

Thekke, V. Sreevidya., Badiadka, Narayana., Yathirajan, H, S., et.al. (2009). Synthesis and characterization of some chalcones and their cyclohexenone derivatives. Cent. Eur. J. Chem. 8(1), 174-181.

Uckun, F.M. (2001). Rationally Designed Anti-mitotic Agents with Pro-Apoptotic Activity Current Pharmaceutical Design. 7, 16, 1627-1639.

Udupa, D., Kulkarni, R., Udupa, S.L., et.al. (1995). Effect of Tridax procumbens Extracts on wound healing. International Journal of Pharmacology. Int. J. Pharm., 33, 37-40.

Viti, G., Namnicine, R., et.al. (1994). New antagonists of platelet-activating factor containing 2-oxazolidinone or 2-morpholinone. Eur. J. Med. Chem., 29, 401.

Wolfe, A., Shimer, G.H., Meehan, T. (1987). Polycyclic aromatic hydrocarbons physically intercalate into duplex regions of denatured DNA. Biochemistry., 26, 6392-6396.

Zuby, G.L., (1988). Biochemistry, McMillan: New York.

(c) 2011 Sharath et al.; This is an Open Access article distributed under the terms of the Creative Commons Attribution License (http://creativecommons.org/licenses/by/2.0), which permits unrestricted use, distribution, and reproduction in any medium, provided the original work is properly cited. 